\title{
ARDL Investigation of Macroeconomic Mechanisms on ASEAN-5 Stock Earnings Equation*
}

\author{
Prasert Chaitip, Siriporn Kannitade \\ Chiang Mai University, Chiang Mai, Thailand
}

The objective of Autoregressive Distributed Lag (ARDL) investigation of macroeconomic mechanisms on ASEAN- $5^{1}$ stock earnings equation can contribute to analyzing and demonstrating macroeconomic forces acting a statistically and economically significant effect on rate of return of securities for a given time through the application of the ARDL approach to cointegration when the variables are mixed degrees of integration in cointegrated time series, i.e. $\mathrm{I}(0)$ and $\mathrm{I}(1)$. This results in a long-run or a short-run relationship between macroeconomic force acting for a given time affecting 24 quarterly rates of return for listed companies in Information and Communication Technologies (ICT) sector of Stock Exchange of Thailand (SET), the Kuala Lumpur Composite Index (KLSE) index (Malaysia), Financial Times Share Index (FTSI), Philippine Stock Exchange (PSE), and Jakarta Composite Index (JKSE) (Indonesia). The impulses of three ASEAN macroeconomic forces $-\mathrm{GDP}_{\mathrm{t}}, \mathrm{EX}_{\mathrm{t}}$, and $\mathrm{INT}_{\mathrm{t}}^{2}$ acting for a given time influence the earnings of selected $23 \mathrm{ICT}$ returns for listed companies on both domestic investments and outsider investments in the same period. This paper has investigated how other-concerning macroeconomic force acting might interrelate with rate of return of securities in the ICT sector, debt and financial innovations, in line with some significant formalized facts. The funding of capital inflow in part of ICT securities was statistically globally significant to recognize significant achievement in ICT specific pathways to distinction as the science of accomplishment. The public sector performing as a key purchaser of ICT security solutions related to integrate the ASEAN exchange members into modern capitalization can lead to adverse effects, such as risky investment-hub interventions due to the mixing financial systems in three ASEAN regional integrations through investments.

Keywords: Information and Communication Technologies (ICT), ASEAN, Autoregressive Distributed Lag (ARDL), macroeconomic factors

\footnotetext{
* This study was accompanied uniquely out of academic interest in the econometric subject, and not in collaboration with any of the stock trade organizations.

Prasert Chaitip, Ph.D., associate professor, Faculty of Economics, Chiang Mai University, Thailand.

Siripron Kannitade, Master's Degree, Faculty of Economics, Chiang Mai University, Thailand.

Correspondence concerning this article should be addressed to Siripron Kannitade, Faculty of Economics, Chiang Mai University, 239 HuayKaew Road, Suthep, Muang, Chiang Mai 50200, Thailand. E-mail: kannitade_s@ hotmail.com.

${ }^{1}$ ASEAN-5 is a five-region of promising potential members of Association of South East Asia (ASEAN), namely Indonesia, Malaysia, Philippines, Singapore, and Thailand.

${ }^{2} \mathrm{GDP}_{\mathrm{t}}$ is a measure of gross domestic product of major countries at time $\mathrm{t}$; $\mathrm{EX}_{\mathrm{t}}$ is a measure of the exchange rate of the major countries per dollar at time $\mathrm{t}$; $\mathrm{INT}_{\mathrm{t}}$ is a measure of interest rate at time $\mathrm{t}$.
} 


\section{Introduction}

The study looks forward to supporting ASEAN economic integration in a broad range of the macroeconomic mechanisms as the predominant determining factors of change on variability of selected 23 ICT returns for listed companies in ASEAN-5 stock exchanges. Combination of unit root test using Augmented Dickey-Fuller (ADF) test and ARDL approach to cointegration was introduced to test the hypothesized relationships covering data for the 24 quarterly, from 2007 to 2012. The findings indicated statistically significant for the long-run and the short-term relationships of $\mathrm{GDP}_{\mathrm{t}}, \mathrm{EX}_{\mathrm{t}}$, and $\mathrm{INT}_{\mathrm{t}}$ affecting on selected ASEAN stock exchanges. Among the excluded, the rate of ICT stock returns was the JKSE and the KLSE index was lower than the upper bound critical value at the 5\% level. Regional stock exchanges have an important role to play in collaborative global efforts towards including but not limited to, collaboration among policy makers, investors, regulators, and companies on matters what related to stock exchanges planning and other awareness initiatives, training/education initiatives.

\section{Statement of the Problem: ICT Sector in ASEAN-5 Exchanges}

ASEAN stock exchanges have certain expectations of the agreement settlement system of ICT that has been characterized as an invaluable platform for economic growth attracting increasing attention from different policy makers, investors, regulators, and companies interconnected to stock exchanges around the world. This economic combination is vital to measure the overall efficiency of ICT as part of leveraging its impact on the economy (Roztocki \& Weistroffer, 2004). Due to planning integration, ASEAN stock exchanges open their door to foreign investors and therefore there has been a strong inflow of foreign investments into ICT sector. Accordingly, a research problem can be abstracted - how ARDL approach to cointegration adopted to analyze economic exogenous factors in ASEAN countries with an influence on the rate of return ICT securities- $\mathrm{RM}_{\mathrm{t}}{ }^{3}$. The ARDL approach in this article starts by clarifying the notion of economic interdependence, which begins to illustrate the remarkable power for the long-run and the short-term relationships, advocate creativity and mobilization of regional wide, and also inspire each of related ICT securities $-\mathrm{RM}_{t}$ in ASEAN stock exchanges to move beyond minimum standards of operation.

\section{Theory and Hypothesis}

Hence, ARDL approach to cointegration model provides a coherent and systematic framework based on concept suggested by Pesaran and Shin (1997) following the study of Chaitip and Chaiboonsri (2008). The empirical estimates for the statistical components obtained from the ARDL method to cointegration analysis are unbiased and efficient given by Narayan (2004). For instance, the long-run and short-run components on the parameters to be estimated simultaneously serve as a counterpart of the realized stock returns volatility dynamics, removing problem associated with omitted variables and autocorrelation. Parameter estimates from ARDL method to cointegration model can segregate dependent and explanatory variables. The ARDL components on estimate models with mixed orders of integration method analyze the long-run relationship when the variables are mixed degrees of integration in cointegrated time series, i.e. I(0) and I(1) (Shrestha, 2006). Moreover, a dynamic Error Correction Model (ECM) can be derived from ARDL through a simple linear transformation (Banerjee, Dolado, \& Mestre, 1998). The ECM integrates the short-run dynamics with the long-run equilibrium without losing long-run information by using the ARDL techniques which can avoid problems resulting from non-stationary time series data.

\footnotetext{
${ }^{3} \mathrm{RM}_{\mathrm{t}}$ is a measure of selected returns for listed companies in ICT sector at time $t$.
} 


\section{Research Design}

\section{Research Framework}

Data on selected 23 ICT rates of return on listed companies in ASEAN-5 stock exchanges show that greater evidence for the variation among the rate of return ICT securities- $\mathrm{RM}_{\mathrm{t}}$ is associated with macroeconomic factors. Using the annual statistical reports covered 24 quarterly, in the period from 2007(Q1) to 2012(Q4), the main objective aims to investigate the short-run and long-run relationships of macroeconomic performances: $\mathrm{GDP}_{\mathrm{t}}, \mathrm{EX}_{\mathrm{t}}$, and $\mathrm{INT}_{\mathrm{t}}$ affecting on the rate of return ICT securities and $\mathrm{RM}_{\mathrm{t}}$ of ASEAN-5 stock exchanges include SET, KLSE, FTSI, PSE, and JKSE.

\section{Definition and Measurement of Variables}

In the first step, the ARDL testing required unit root testing on a dependent variable as selected 23 ICT returns for listed companies and independent variables $\left(\mathrm{GDP}_{\mathrm{t}}, \mathrm{EX}_{\mathrm{t}}\right.$, and $\left.\mathrm{INT}_{\mathrm{t}}\right)$ under investigation. Unit root testing on variables as a necessary requirement for experimentation is used to identify the order of adopted variables. Conducting an ADF test includes lagged values of the difference of the variable in the regression in a time series hypothesized on rate of return ICT listed companies- $\mathrm{RM}_{\mathrm{t}}$. After having estimated the unit root test, the study clearly accepts the hypotheses that the variables are either I(0) or I(1). Data on selected 23 ICT returns for listed companies in ASEAN-5 stock exchanges were examined in predicting stable formulated ARDL function of the long-run relationship and the short-run ECM. The paper adopted ARDL used with a mixture of I(0) and I(1) data as hypothesized by Pesaran and Shin (1997). The empirical construction of ARDL equation for the study is specified as follows:

$$
\begin{aligned}
\triangle R M_{t}^{A S E A N} & =\alpha_{0}+\sum_{i=1}^{p} \beta_{i} \Delta R M_{t-i}^{A S E A N}+\sum_{i=1}^{p} \delta_{i} \Delta \ln G D P_{t-i}^{A S E A N}+\sum_{i=1}^{p} \varepsilon_{i} \Delta \ln I N T+\sum_{t-i}^{p} \lambda_{i} \Delta \ln E X_{t-i} \\
& +\lambda_{1} \ln R M_{t-1}+\lambda_{2} \ln G D P_{t-1}+\lambda_{3} \ln I N T_{t-1}+\lambda_{3} \ln E X_{t-1}+u_{t}
\end{aligned}
$$

An explicit function $\mathrm{RM}_{\mathrm{t}}=\mathrm{F}\left(\mathrm{GDP}_{\mathrm{t}}, \mathrm{EX}_{\mathrm{t}}, \mathrm{INT}_{\mathrm{t}}\right)$ can be stated in formal term as $\mathrm{F}\left(\mathrm{RM}_{\mathrm{t}} \mid \mathrm{GDP}_{\mathrm{t}}, \mathrm{EX}_{\mathrm{t}}, \mathrm{INT}_{\mathrm{t}}\right)$.

\section{Research Method}

\section{Results of Unit-Root Tests}

Using augmented ADF, the output results indicated the order of stationary at $\mathrm{I}(0)$ and $\mathrm{I}(1)$. The statistical models based on ARDL approach provide an alternative test for examining the significance of the impact of macroeconomic performances including $\mathrm{GDP}_{\mathrm{t}}, \mathrm{EX}_{\mathrm{t}}$, and $\mathrm{INT}_{\mathrm{t}}$ affecting 23 ICT listed companies in selected ASEAN-5 stock exchanges.

\section{Results on ARDL Approach to Cointegration:}

The long-run results of cointegration test based on ARDL. Using cross-country data of five ASEAN countries, the study examined macroeconomic mechanisms as the predominant determining factors influencing selected 23 ICT returns for listed companies over the period from 2007(Q1) to 2012(Q4). Table 1 reports descriptive statistics for testing the existence of a level long-run relationship (the value of $F$-statistics). The effort of ARDL approach's result on upper and lower bounds has become a benchmark for the findings. Bounds tests computed to compare the upper and lower bounds in critical values provide strong evidence in favor of a significant long-run relationship among the variables. Three out of five ASEAN stock earnings equations rejected the null hypothesis of no cointegrating equations and 12 ICT returns for listed companies of SET, FTSI, and PSE, indicating a strong evidence in favor of a significant long-run relationship. The alternative hypothesis 
of the existence of cointegration among variables at the 5\% was accepted showing the cointegrating relationship between pairs of variables. The critical value bounds of the $F$-statistics are provided in intercept and trend $(k=3)^{4}$. The results of the bounds " $F$ " tests showed that the null hypothesis of no cointegration can be rejected at the $5 \% .^{5}$ For all selected 12 ICT returns for listed companies of SET, FTSI, and PSE, the overall results of bounds testing procedures are supportive of the theory. Twelve ICT returns for listed companies of SET, FTSI, and PSE indicated that $F$-statistics were higher than the upper bound critical value at the 5\% level. The statistical outputs confirmed the existence of a stable long-run relationship (Banerjee et al., 1998; Hazem \& Anchada, 2008; Ouattara, 2004). From the overall results from the cointegrating equations of JKSE and KLSE, it found that the lower bounds were lower than the upper bounds critical values at the $5 \%$ level $^{6}$.

Table 1

F-statistics for Testing the Existence of a Long-run on ARDL Model ${ }^{7}$

\begin{tabular}{|c|c|c|c|}
\hline \multirow{2}{*}{ Function } & \multirow{2}{*}{$F$-statistics } & \multicolumn{2}{|c|}{$5 \%$ critical value } \\
\hline & & lower bounds $\mathrm{I}(0)$ & upper bounds I(1) \\
\hline \multicolumn{4}{|l|}{ Thailand stock exchanges } \\
\hline $\mathrm{F}\left(\mathrm{AVANCE}_{\mathrm{t}} \mid \mathrm{GDP}_{\mathrm{t}}, \mathrm{EX}_{\mathrm{t}}, \mathrm{INT}_{\mathrm{t}}\right)$ & $6.50 *$ & 4.066 & 5.119 \\
\hline $\mathrm{F}\left(\mathrm{DTAC}_{\mathrm{t}} \mid \mathrm{GDP}_{\mathrm{t}}, \mathrm{EX}_{\mathrm{t}}, \mathrm{INT}_{\mathrm{t}}\right)$ & $12.46^{*}$ & 4.066 & 5.119 \\
\hline $\mathrm{F}\left(\mathrm{INTUCH}_{\mathrm{t}} \mid \mathrm{GDP}_{\mathrm{t}}, \mathrm{EX}_{\mathrm{t}}, \mathrm{INT}_{\mathrm{t}}\right)$ & $54.96^{*}$ & 4.066 & 5.119 \\
\hline $\mathrm{F}\left(\mathrm{THCOM}_{\mathrm{t}} \mid \mathrm{GDP}_{\mathrm{t}}, \mathrm{EX}_{\mathrm{t}}, \mathrm{INT}_{\mathrm{t}}\right)$ & $8.18 *$ & 4.066 & 5.119 \\
\hline $\mathrm{F}\left(\mathrm{TURE}_{\mathrm{t}} \mid \mathrm{GDP}_{\mathrm{t}}, \mathrm{EX}_{\mathrm{t}}, \mathrm{INT}_{\mathrm{t}}\right)$ & $6.47 *$ & 4.066 & 5.119 \\
\hline \multicolumn{4}{|l|}{ Straits times } \\
\hline $\mathrm{F}\left(\mathrm{INN}_{\mathrm{t}} \mid \mathrm{GDP}_{\mathrm{t}}, \mathrm{EX}_{\mathrm{t}}, \mathrm{INT}_{\mathrm{t}}\right)$ & $15.55^{*}$ & 4.066 & 5.119 \\
\hline $\mathrm{F}\left(\mathrm{STH}_{\mathrm{t}} \mid \mathrm{GDP}_{\mathrm{t}}, \mathrm{EX}_{\mathrm{t}}, \mathrm{INT}_{\mathrm{t}}\right)$ & $6.47 *$ & 4.066 & 5.119 \\
\hline $\mathrm{F}\left(\mathrm{NERT}_{\mathrm{t}} \mid \mathrm{GDP}_{\mathrm{t}}, \mathrm{EX}_{\mathrm{t}}, \mathrm{INT}_{\mathrm{t}}\right)$ & $7.98 *$ & 4.066 & 5.119 \\
\hline $\mathrm{F}\left(\mathrm{I} \mathrm{I}_{\mathrm{t}} \mid \mathrm{GDP}_{\mathrm{t}}, \mathrm{EX}_{\mathrm{t}}, \mathrm{INT}_{\mathrm{t}}\right)$ & $9.38^{*}$ & 4.066 & 5.119 \\
\hline \multicolumn{4}{|l|}{ Philippines stock exchanges } \\
\hline $\mathrm{F}\left(\mathrm{TBGI}_{\mathrm{t}} \mid \mathrm{GDP}_{\mathrm{t}}, \mathrm{EX}_{\mathrm{t}}, \mathrm{INT}_{\mathrm{t}}\right)$ & $20.88^{*}$ & 3.219 & 4.378 \\
\hline $\mathrm{F}\left(\mathrm{ISM}_{\mathrm{t}} \mid \mathrm{GDP}_{\mathrm{t}}, \mathrm{EX}_{\mathrm{t}}, \mathrm{INT}_{\mathrm{t}}\right)$ & $27.38^{*}$ & 3.219 & 4.378 \\
\hline $\mathrm{F}\left(\mathrm{PAX}_{\mathrm{t}} \mid \mathrm{GDP}_{\mathrm{t}}, \mathrm{EX}_{\mathrm{t}}, \mathrm{INT}_{\mathrm{t}}\right)$ & $8.31 * *$ & 3.219 & 4.378 \\
\hline
\end{tabular}

Notes. Significant at $1 \%$ level*, $5 \%$ level**, $10 \%$ level***. Source: From computed.

As presented on Table 2, in SET, five major ICT publicly listed companies of ICT sectors namely: Advanced Information Service PCL (ADVANCE), Total Access Communication PCL (DTAC), Intouch Holdings PCL (INTUCH), Thaicom PCL (THCOM), and True Corp PCL (TURE) were selected. The alternative hypothesis of $\mathrm{AVANCE}^{8}$ at the $5 \%$ showed the cointegrating relationship between pairs of variables. The critical value bounds of the $F$-statistics are provided in intercept and trend $(k=3)$. The findings are

\footnotetext{
${ }^{4} k$ is the number of regressors for dependent variable in ARDL models.

${ }^{5}$ Significance level less than 0.05 for all different specification confirmed tests $r 0, r 1$, and $r 2$, respectively, of $\mathrm{H}(0), \mathrm{H}(1)$, and $\mathrm{H}(2)$ against $\mathrm{H}(3)$.

${ }^{6}$ The adversary revealed information which was not critical value.

${ }^{7}$ To examine the cointegrating relationship, Wald Test or the $F$-test for the joint significance of the coefficients of the lagged variables are applied with the null hypothesis- $\mathrm{H}(0)$, indicating no cointegration against the alternative hypothesis of the existence of cointegration among variables. $F$-statistics are computed to compare the upper and lower bounds critical values provided by Pesaran (1997).

${ }^{8} \mathrm{H}(3)$ accepted $r=2$ in favor of $r=3$
} 
supportive of the claim that four rates of return on ICT publicly listed companies (AVANCE, INTUCH, THCOM, and TURE) are transforming Thailand economy at a rapid pace. The empirical results imply that Thailand GDP has a negative and significant long-run effect on rates of return on AVANCE and INTUCH ${ }^{9}$. In contrast, Thailand GDP has a positive and significant long-run effect on rates of return on THCOM and TURE $^{10}$ except DTAC indicating no cointegration. Exchange rate (EX) in Thailand has a negative and significant long-run effect on rates of return of AVANCE and INTUCH, but a positive and significant long-run effect on rates of return of TURE except DTAC and THCOM indicating no cointegration. Interest Rate (INT) in Thailand has a positive and significant long-run effect on rates of return of AVANCE and THCOM.

Table 2

Results of the Long-run Relationship in ICT Sector Based on ARDL Approach

\begin{tabular}{|c|c|c|c|c|}
\hline Function & Constant & $\ln \left(\mathrm{GDP}_{\mathrm{t}}\right)$ & $\ln \left(\mathrm{EX}_{\mathrm{t}}\right)$ & $\ln \left(\mathrm{INT}_{\mathrm{t}}\right)$ \\
\hline \multicolumn{5}{|c|}{ Thailand stock exchanges } \\
\hline \multirow{2}{*}{ ln AVANCE } & $38.40 * *$ & $-1.34 *$ & $-1.70 * * *$ & $0.08 * * *$ \\
\hline & $(-2.92)$ & $(-2.99)$ & $(-2.09)$ & $(-1.81)$ \\
\hline \multirow{2}{*}{$\ln$ DTAC } & 170.59 & -5.65 & -9.64 & -0.12 \\
\hline & $(-3.51)$ & $(-3.49)$ & $(-3.32)$ & $(-0.99)$ \\
\hline \multirow{2}{*}{ ln INTUCH } & $189.52 * *$ & $-6.46^{* *}$ & $-9.52 * *$ & -0.053 \\
\hline & $(-5.47)$ & $(-5.89)$ & $(-4.01)$ & $(-0.78)$ \\
\hline \multirow{2}{*}{$\ln$ THCOM } & $150.35 * *$ & $2.28 * *$ & -4.44 & $0.27 * *$ \\
\hline & $(-3.69)$ & $(-2.65)$ & $(-1.77)$ & $(-3.86)$ \\
\hline \multirow{2}{*}{ ln TURE } & $-77.14 * *$ & $2.28 * *$ & $6.22 * *$ & 0.16 \\
\hline & $(-3.02)$ & $(-2.65)$ & $(2.97)$ & $(-1.27)$ \\
\hline \multirow{2}{*}{$\ln$ INN } & $168.15^{*}$ & $-6.86^{*}$ & $-5.99 * * *$ & $1.30 *$ \\
\hline & $(-4.02)$ & $(-4.09)$ & $(-1.94)$ & $(-5.58)$ \\
\hline \multirow{2}{*}{$\ln \mathrm{STH}$} & $0.61 * *$ & $1.87 *$ & 0.05 & $-15.89 * *$ \\
\hline & $(-2.21)$ & $(-3.48)$ & $(-0.97)$ & $(-2.3029)$ \\
\hline \multirow{2}{*}{ ln NERT } & $106.69 *$ & $-4.34 *$ & $0.67 *$ & $-3.69 * *$ \\
\hline & $(-3.93)$ & $(-3.98)$ & $(-4.36)$ & $(-2.16)$ \\
\hline \multirow{2}{*}{$\ln \mathrm{I} 2 \mathrm{I}$} & $111.61 * *$ & $-4.54 *$ & -0.11 & -2.677 \\
\hline & $(-3.06)$ & $(-3.10)$ & $(-0.51)$ & $(-1.13)$ \\
\hline \multirow{2}{*}{ ln TBGl } & $-18.77 * *$ & -0.08 & $4.98 * *$ & $1.03 * *$ \\
\hline & $(-4.63)$ & $(-.68)$ & $(-3.84)$ & $(-3.70)$ \\
\hline \multirow{2}{*}{ ln ISM } & $13.63 *$ & $-0.25^{* *}$ & -1.28 & $-2.15^{*}$ \\
\hline & $(-3.36)$ & $(-2.50)$ & $(-1.61)$ & $(-7.94)$ \\
\hline \multirow{2}{*}{$\ln$ PAX } & 5.25 & $-0.82 *$ & $3.98 * * *$ & $-1.67 *$ \\
\hline & $(-1.01)$ & $(-4.22)$ & $(-2.28)$ & $(-7.79)$ \\
\hline
\end{tabular}

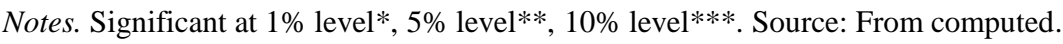

In FTSI, four major ICT publicly listed companies of ICT sectors namely: StarHub Ltd (STH), Innopac Holdings Ltd (INN), Nera Telecommunications Ltd (NERT), and S I2I Ltd (I2I) were selected. The alternative

\footnotetext{
${ }^{9}$ Results suggest the rejection of the null hypothesis of no long-run relationship between GDP and AVANCE, GDP and INTUCH.

${ }^{10}$ Results suggest the rejection of the null hypothesis of no long-run relationship between GDP and THCOM, GDP and TURE.
} 
hypothesis, $\mathrm{H}(3)$ accepted $r=2$ in favor of $r=3$ at the 5\% showing the cointegrating relationship among three pairs of variables. The critical value bounds of the $F$-statistics are provided in intercept and trend $(k=3)$. The empirical results imply that Singapore GDP has a negative and significant long-run effect on rates of return on INN, NERT and in contrast, a positive and significant long-run effect on rates of return on STH and I2I. EX in Singapore has a negative and significant long-run effect on rates of returns of INN, but a positive and significant long-run effect on rates of return on NERT. INT in Singapore has a negative and significant long-run effect on rates of return on INN, but a positive and significant long-run effect on rates of return on STH and NERT.

In PSE, three major publicly listed companies of ICT sectors namely: Transpacific Broadband Group International Inc (TBGl), ISM Communications Corp (ISM), and Paxys Inc (PAX) were selected. The alternative hypothesis, $\mathrm{H}(3)$ accepted at the 5\% showing the cointegrating relationship among three pairs of variables. The critical value bounds of the $F$-statistics are provided in intercept and trend $(k=3)$. The empirical results imply that Philippines GDP has a negative and significant long-run effect on ISM and PAX. EX in Philippines has a positive and significant long-run effect on rates of return on TBGl and PAX. INT in Philippines has a negative and significant long-run effect on rates of return ISM and PAX, but a positive and significant long-run effect on rates of return in TBGl.

The results of the short-run ECM selected based on ARDL approach to cointegration. The results of short-run relationships of macroeconomic forces for each of the hypothesized relationships are reported in Table 3. However, the findings indicated that all these variables as macroeconomic forces are significant. There are short-run relationships of macroeconomic forces on rates of return of eight publicly listed companies of ICT sectors namely: ADVANCE, INTUCH, INN, I2I, STH, NERT, ISM, and PAX being statistically significant at $0.1^{11}$. Speed of adjustment coefficients equals to the coefficients of the error correction terms; $\mathrm{ECT}_{t-1 s}$ are $-1.465,-1.465,-1.63,-1.65,-1.98,-1.63,-1.23$, and -1.90 and have the expected signs. ${ }^{12}$

Table3

Results of the Short-run Relationship in ICT Sector Based on ARDL Approach

\begin{tabular}{|c|c|c|c|c|c|c|c|c|}
\hline \multirow[b]{2}{*}{ Variable } & \multicolumn{5}{|c|}{ Error correction representation of ARDL Model } & \multicolumn{3}{|c|}{ Key regression statistics } \\
\hline & $\Delta \ln \mathrm{GDPt}$ & $\Delta \ln \mathrm{EX}_{\mathrm{t}}$ & $\Delta \ln \mathrm{INT}_{\mathrm{t}}$ & $C$ & $\operatorname{ECM}(-1)$ & $R^{2}$ & $F$-test & $\begin{array}{l}\text { Durbin-Watson } \\
\text { statistic (DW) }\end{array}$ \\
\hline \multicolumn{9}{|c|}{ Thailand stock exchanges } \\
\hline ln AVANCE & $\begin{array}{l}-1.03 \\
(-1.60)\end{array}$ & $\begin{array}{l}-2.49 * * * \\
(-1.90)\end{array}$ & $\begin{array}{l}0.11 * * * \\
(-1.60)\end{array}$ & $\begin{array}{l}56.27 * * \\
(-1.76)\end{array}$ & $\begin{array}{l}-1.465 * \\
(-6.16)\end{array}$ & 0.722 & $7.79 *$ & 1.82 \\
\hline ln DTAC & $\begin{array}{l}-4.83 * * * \\
(-2.69)\end{array}$ & $\begin{array}{l}-2.49 * * * \\
(-1.60)\end{array}$ & $\begin{array}{l}0.13 \\
-0.58\end{array}$ & $\begin{array}{l}424.8 * * \\
-3.59\end{array}$ & $\begin{array}{l}-2.49 \\
(-4.06)\end{array}$ & 0.99 & $8.30 * *$ & 2.145 \\
\hline In INTUCH & $\begin{array}{l}-3.02 * * \\
(-5.34)\end{array}$ & $\begin{array}{l}-6.75 * * \\
(-4.35)\end{array}$ & $\begin{array}{l}0.24 \\
-1.75\end{array}$ & $\begin{array}{l}429.7 * \\
-7.49\end{array}$ & $\begin{array}{l}-1.465^{*} \\
(-6.16)\end{array}$ & 0.98 & $9.42 * *$ & 3.069 \\
\hline ln THCOM & $\begin{array}{l}-3.49 * \\
(-3.61)\end{array}$ & $\begin{array}{l}-3.61 \\
(-1.25)\end{array}$ & $\begin{array}{l}-0.13 * * \\
(-0.72)\end{array}$ & $\begin{array}{l}318.7 * * \\
(-3.2)\end{array}$ & $\begin{array}{l}-2.12 \\
(-9.25)\end{array}$ & 0.988 & $28.81 *$ & 2.645 \\
\hline ln TURE & $\begin{array}{l}2.269 \\
(-1.25)\end{array}$ & $\begin{array}{l}-1.25 \\
(-.35)\end{array}$ & $\begin{array}{l}0.232 \\
-0.85\end{array}$ & $\begin{array}{l}-207.3^{* *} \\
(-2.35)\end{array}$ & $\begin{array}{l}-2.68 \\
(-3.56)\end{array}$ & 0.941 & $7.37 *$ & 2.969 \\
\hline
\end{tabular}

Table 3 continued

\footnotetext{
${ }^{11}$ The examination results according to $-2<$ ECM $(-1)<0$ are statistically significant.

${ }^{12}$ Adjustment of short run refers to the speed of adjustment in the equilibrium or back to the long-run equilibrium relationship.
} 


\begin{tabular}{|c|c|c|c|c|c|c|c|c|}
\hline \multirow[b]{2}{*}{ Variable } & \multicolumn{5}{|c|}{ Error correction representation of ARDL Model } & \multicolumn{3}{|c|}{ Key regression statistics } \\
\hline & $\Delta \ln \mathrm{GDPt}$ & $\Delta \ln \mathrm{EX}_{\mathrm{t}}$ & $\Delta \ln \mathrm{INT}_{\mathrm{t}}$ & $C$ & $\operatorname{ECM}(-1)$ & $R^{2}$ & $F$-test & $\begin{array}{l}\text { Durbin-Watson } \\
\text { statistic (DW) }\end{array}$ \\
\hline \multicolumn{9}{|c|}{ Straits times } \\
\hline \multirow{2}{*}{$\ln$ INN } & 1.82 & $-.048 * * *$ & 0.49 & $275.1^{*}$ & $-1.63 *$ & 0.866 & $18.23 *$ & 2.316 \\
\hline & -0.67 & $(-0.01)$ & -0.6 & -3.77 & $(-8.76)$ & & & \\
\hline \multirow{2}{*}{$\ln \mathrm{STH}$} & $1.01 * * *$ & $0.62 *$ & -0.037 & $-26.2 * *$ & $-1.65^{*}$ & 0.84 & $9.01 *$ & 1.809 \\
\hline & $(-2.12)$ & $(-0.65)$ & $(-0.22)$ & $(-2.20)$ & $(-5.94)$ & & & \\
\hline \multirow{2}{*}{ ln NERT } & -3.2 & $1.33 *$ & $-7.31 * * *$ & $211.8 * *$ & $-1.98 *$ & 0.772 & $6.30 *$ & 2.279 \\
\hline & $(-1.28)$ & $(-3.09)$ & $(-1.82)$ & $(-2.77)$ & $(-4.76)$ & & & \\
\hline \multirow{2}{*}{$\ln \mathrm{I} 2 \mathrm{I}$} & -3.31 & 0.56 & -4.38 & $182.7 * *$ & $-1.63 *$ & 0.77 & $5.76^{*}$ & 2.193 \\
\hline & $(-1.54)$ & $(-0.86)$ & $(-1.17)$ & $(-2.96)$ & $(-4.96)$ & & & \\
\hline \multicolumn{9}{|c|}{ Philippines stock exchanges } \\
\hline \multirow{2}{*}{ ln TBGl } & $0.52 *$ & 2.75 & $1.36^{*}$ & $-45.7 *$ & -2.44 & 0.968 & $9.57 *$ & 2.244 \\
\hline & $(-3.61)$ & $(-0.97)$ & $(-3.56)$ & $(-5.29)$ & $(-6.12)$ & & & \\
\hline \multirow{2}{*}{ ln ISM } & $0.29 * *$ & $5.26 *$ & $-1.25^{*}$ & $16.7 *$ & $-1.23 *$ & 0.942 & $32.78 *$ & 2.013 \\
\hline & $(-2.39)$ & $(-3.4)$ & $(-5.07)$ & $(-3.69)$ & $(-10.21)$ & & & \\
\hline \multirow{2}{*}{$\ln \mathrm{PAX}$} & -0.2 & $7.81 * * *$ & $-3.18 * *$ & $9.99 * *$ & $-1.90 *$ & 0.98 & $41.27 *$ & 3.221 \\
\hline & -0.87 & -2.14 & $(-7.92)$ & -1.02 & $(-14.9)$ & & & \\
\hline
\end{tabular}

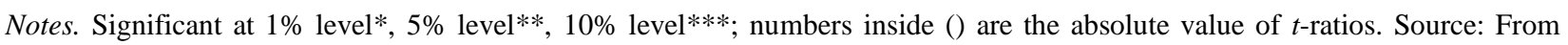
computed.

\section{Conclusions}

Regional stock exchanges have an important role to play in collaborative global efforts towards including but not limited to, collaboration among policy makers, investors, regulators, and companies on matters related to stock exchanges planning and other awareness initiatives, training/education initiatives. This study searches the short-run and the long-run effects of macroeconomic forces on the earnings of selected ICT for listed companies in ASEAN-5 stock using 24 quarterly, in the period from 2007(Q1) to 2012(Q4). As a momentary conclusion, testing procedures revealed that the recommended ARDL tests for causal link are applied, and their hypothetical distributions under the null and suitably defined local alternatives are derived. The empirical procedures are demonstrated by an investigation of the earnings equation including selected 23 ICT returns for listed companies in ASEAN-5 stock exchanges. Three out of five ASEAN stock earnings equations rejected the null hypothesis of no cointegrating equations and 12 ICT returns for listed companies of SET, FTSI, and PSE, indicating strong evidence in favor of a significant long-run relationship. Macroeconomic forces acting for a given time tested a long-run doctrine at the bases of ARDL approach and exhibited a profound respect for and understanding of the existence of a stable long-run relationship among pairs of macroeconomic performances and the rate of returns for eight selected ICT listed companies in ASEAN stock exchanges.

\section{References}

Banerjee, A., Dolado, J. J., \& Mestre, R. (1998). Error-correction mechanism tests for cointegration in a single-equation framework. Journal of Time Series Analysis, 19(3), 267-283.

Chaitip, P., \& Chaiboonsri, C. ( 2008). ARDL approach in estimating international tourism demand in Thailand. Proceedings from International Conference on Applied Economics-ICOAE, pp. 215-227.

Hazem, D., \& Anchada, C. (2008). A study of market-wide short-selling restrictions (Working Paper, Department of Applied 
Economics and Management Cornell University, Ithaca, New York, USA, pp. 14853-17801).

Narayan (2004). Trends in socioeconomic inequalities in mortality in developing countries. The case of child survival in São Paulo, Brazil. Demography, 41(3), 443-464.

Ouattara, B. (2004). Modelling the long run determinants of private investment in Senegal (The School of Economics Discussion Paper Series 0413, Economics, University of Manchester).

Pesaran, M. H., \& Shin, Y. (1997). An Autoregressive distributed lag modeling approach to cointegration analysis (DAE Working Paper Series, Department of Economics, University of Cambridge).

Roztocki, N., \& Weistroffer, H. R. (2004). Evaluating information technology investments in emerging economies using activity-based costing. Electronic Journal of Information Systems in Developing Countries, 19(2), 1-6.

Shrestha, M. (2006). Mountain agriculture and land-cover change in the Nepal Himalaya. In F. P. Martin (Ed.), Global change in mountain regions (pp. 232-233). Duncow: Sapiens Publishing. 